\title{
LISÄKOULUTUS KOULUTUSTALON KATTOPUUTARHAKSI
}

$\mathrm{T}$ yössä olevien ammattilaisten suosituimpiin jatkokoulutuksiin kuuluu koulutus, joka valmistaa johtamisen erikoisammattitutkintoon (JET). Reilusta 6000:sta koulutukseen osallistuvasta puolet on suorittanut korkeakoulututkinnon. Toden totta: korkeakoulutettujen lisäkoulutus on suurelta osin toisen asteen vastuulla. Havainto on hämmentävä maassa, jossa on yksi korkeakoulu 100000 asukasta kohden.

Yliopistoissa tutkintoon johtava aikuiskoulutus on suurelta osin täydennyskoulutusta. Aikuisista tutkinto-opiskelijoista peräti 42 prosenttia suorittaa toista korkeakoulututkintoaan. Kun yliopistoissa opiskelijoiden määrä on kasvanut määrärahoja nopeammin, tutkintoputken käyttö täydennyskoulutukseen ei vaikuta mielekkäältä.

Opiskelijan ja hänen työnantajansa kannalta tilanne on yksinkertainen. Uutta osaamista kannattaa hankkia sieltä, missä koulutuksen hintalaatu-suhde on mielekkäin. Tämä vie diplomi-insinöörin opiskelemaan ammattitutkintoa ja voi saada maisterin aloittamaan uudet maisteriopinnot.

Ammattitutkinnon periaate sopii hyvin korkeakoulutettujenkin täydennys- ja lisäkoulutuksen pohjaksi. Olemassa oleva ja työssä syventynyt osaaminen on perusta, jonka päälle koulutuksen antamat uudet tiedot ja taitojen kehittyminen rakentuvat. Lopputuloksena on työssä tarvittavan ammattitaidon syventäminen tai laajentaminen. Toisen samantasoisen perustutkinnon suorittaminen sopii harvoin tähän tarkoitukseen.

Yksi asia on kuitenkin selvä. Lisä- ja täydennyskoulutuksen julkinen rahoitus suuntautuu eri tavoin eri koulutustasoille. Yhteiskunta tukee taloudellisesti näyttötutkintoihin valmistavaa koulutusta. Esimerkiksi JET-tutkintoon valmistautuvassa koulutuksessa 90 prosenttia kouluttautuu oppisopimuksella. Myös ammattikorkeakoulujen täydennyskoulutuksena järjestämiä erikoistumisopintoja subventoidaan. Yliopistojen täydennyskoulutus on liiketaloudellisesti hinnoiteltua, mikä rajoittaa oppijoiden mahdollisuuksia hyödyntää tarjontaa.
Lienee kohtuullista, että eri koulutusasteet saisivat samantapaiset edellytykset lisä- ja täydennyskoulutuksen järjestämiseen.

Toisaalta on syytä muistaa, että JET on kehittynyt hyväksi tuotteeksi. Se on työelämälähtöinen ja toteutukseltaan joustava. JET voidaan soveltaa organisaation tai toimialan tarpeisiin. Yliopistoilta ei vastaavia lisäkoulutuksen tuotteita löydy.

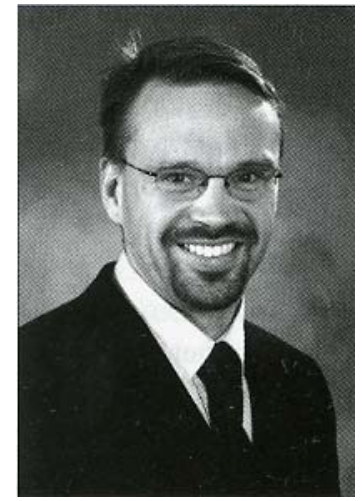

Petri Lempinen
Onko se oikeasti ongelma, että diplomi-insinööri tai maisteri suorittaa lisäkoulutuksena muodollisesti toisen asteen koulutukseen kuuluvan tutkinnon? Ettei vain kyse sittenkin olisi reviiriajattelusta tai kateudesta. Onko kyseessä enemmän tutkintojärjestelmien hierarkioiden kuin oppijoiden ongelma?

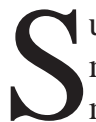

uomi vastaa kilpailuun globalisoituvassa maailmassa hyvällä ammattitaidolla ja osaa misella. Näin isokenkäiset ovat meille tvuutisissa opettaneet. Koulutuspanostukset ovat Suomessa korkeat ja niiden tulokset osin parempia ja usein yhtä hyviä kuin muissa maissa. Suomen menestyksen salaisuus lienee siinä, että emme ole sortuneet pitämään koulutusjärjestelmäämme parhaana mahdollisena.

Toisaalta herrat ja rouvat kabineteissa vaativat meitä olemaan töissä nykyistä pidempään. Koulutuspolitiikan keino tämän tukemiseen on lähinnä lisä-, täydennys- ja uudelleenkoulutuksen kehittäminen ja jopa lisääminen.

Työnantajalla on vastuu henkilöstönsä kouluttamisesta. Palkansaajan intressinä on ammattitaidon ylläpitäminen. Jos kansantaloudelle tai yritykselle osaaminen merkitsee kilpailukykyä, palkansaajalle ammattitaito on osa työsuhdeturvaa. Julkisen koulutusjärjestelmän tehtävänä on mahdollisimman tasapuolisesti tarjota mahdollisuuksia työssä tarvittavan ammattitaidon kehittämiseen. Investointi koulutukseen on sijoitus 
paitsi yksilön ja työpaikan, myös Suomen tulevaisuuteen.

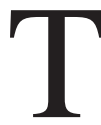
yöelämä edellyttää suoritteita ja tuloksia. Suorituspaineet tuntuvat kasvavan jatkuvasti ja muutoksista on tullut arkipäivää. Samalla epävarmuus työelämässä on lisääntynyt. Ammattitaito ja oppiminen ovat keinoja tulosten saavuttamiseksi.

Koulutus ei kuitenkaan saa olla itsetarkoitus ja pakko vaan väline. Fiksussa työpaikassa osaamisen kehittäminen on strateginen osa toimintaa. Valtaosa ammattitaidon kehittymisestä tapahtuu työtehtävien yhteydessä, ei kursseilla. Lisäkoulutuksen haaste on kurssijaksolla opitun kehittäminen ammattitaidoksi työn arjessa.

Yksittäisten palkansaajien ja työnantajien mahdollisuudet sijoittaa aikaa, rahaa ja vaivaa koulutukseen vaihtelevat. Yhteiskunnan vaatimukset kilpailukyvyn ja työllisyyden parantamiseksi kuitenkin edellyttävät, että lähes jokainen työelämässä oleva tai sinne haluava voi edes joskus kouluttautua. Tämän vuoksi julkisen koulutusjärjestelmän kehittämisessä on huomioitava eri toimialojen ja eri henkilöstöryhmien erilaiset mahdollisuudet kouluttautua.

Yliopistojen lisäkoulutuksen tuote voisi olla tiedepohjainen ja korkeakoulutetuille suunnattu erikoistumisopinto. Niiden avulla yliopistot voisivat siirtää osaamistaan ja tutkimuksen uusia tuloksia työelämän jatkuvasti muuttuviin tarpeisiin. Toistaiseksi erikoistumisopintoja ei kannata kehittää, koska niiden järjestämiseen ei saa valtion rahoitusta. Avaimet pattitilanteen aukeamiseen ovat opetus- ja valtiovarainministeriöissä.

Yliopistojen täydennyskoulutusta on kehitettävä myös julkisena tehtävänä, jotta yliopistojen osaaminen saadaan mahdollisimman laajasti aikuisväestön ulottuville. Nykytilanne, jossa täydennyskoulutus kohdistuu maksukykyisten työnantajien ylempiin toimihenkilöihin avoimen yliopiston huolehtiessa matalapalkka-alojen naisista, on kestämätön.

Julkinen koulutusjärjestelmä kuvataan Suomessa kaaviolla, jonka yksi pilari johtaa ammattikoulun kautta ammattikorkeakouluun. Rinnakkainen pilari johtaa lukiosta yliopistoon. Ammattitutkinnot ovat jossain sivulla ja muu täydennyskoulutus puuttuu kokonaan. Suomalainen koulutusjärjestelmä on äärimmäisen tutkintopainotteinen, joka näkyy myös rahoituksessa.
Entä jos suomalainen koulutusjärjestelmä piirrettäisiin kaavion sijaan taloksi, jossa peruskoulun yläpuolella ovat nuoriso- ja aikuiskoulutuksen kerrokset?

Koulutustalon sokkelin muodostaa luonnollisesti yleissivistävä koulutus, jonka päälle rakennetaan ammatillisesti eriytyneen koulutukseen kerrokset eli perustutkinnot. Kattopuutarhoina, joista työelämään siirtyneet saisivat inspiraatiota ja virkistystä, olisivat lisäkoulutuksen, vapaan sivistystyön ja tieteellisen jatkokoulutuksen väylät. Lisäkoulutuksen osastosta löytyisivät näyttötutkinnot, korkeakoulujen erikoistumisopinnot ja ehkä myös ylempi ammattikorkeakoulututkinto.

Voiko JET:n suosio kuvastaa myös työelämän kehittämisen tarpeita? Johtaminen ja esimiestyö ovat monien tutkimusten mukaan kipupisteitä suomalaisilla työpaikoilla. Esimieskaarti uusiutuu vanhojen jäädessä eläkkeelle. Uusia esimiehiä valmennetaan ja koulutetaan työssään jo - toivottavasti - pätevöityneistä. JET on oiva väline heidän taitojensa kehittämiseen.

Etenkin pk-yritysten ja julkisen sektorin palveluksessa olevien esimiesten kouluttaminen on julkisen koulutusjärjestelmän tehtävä eikä sitä voi toteuttaa vain liiketaloudellisin periaattein. Myös aikuiskoulutuksena tarjottavien korkeakoulututkintojen on annettava valmiuksia esimiehenä toimimiseen. Ylempään amk-tutkintoon johtavia koulutusohjelmia on kehitettävä johtamis- ja esimieskoulutuksena eri toimialojen tarpeisiin.

Jos korkeakoulut haluavat nykyistä leveämmän siivun lisäkoulutuksesta, kannattaa niiden vastata myös esimieskoulutuksen haasteeseen.

\section{Petri Lempinen}

